\title{
Comparison of Telbivudine and Entecavir Therapy on Nephritic Function and Drug Resistance in Patients with Hepatitis B Virus-Related Compensated Cirrhosis
}

\author{
Huajiang Shen ${ }^{a}$ Feng Ding ${ }^{a}$ Zhiwei Wang ${ }^{a}$ Fang Sun ${ }^{a}$ Yafeng Yu ${ }^{a}$ \\ Jiankang Zhou ${ }^{\mathrm{a}}$ Wenfang $\mathrm{Xu}^{\mathrm{a}}$ Jianchao $\mathrm{Ni}^{\mathrm{a}}$ Jiangang Wang ${ }^{\mathrm{a}}$ Yida Yang ${ }^{\mathrm{b}}$ \\ aDepartment of Hepatology, ShaoXing Municipal Hospital, ShaoXing, Zhejiang Province, ${ }^{b}$ Collaborative \\ Innovation Center for Diagnosis and Treatment of Infectious Diseases, State Key Laboratory for \\ Diagnosis and Treatment of Infectious Disease, Department of Infectious Diseases, First Affiliated \\ Hospital of Zhejiang University School of Medicine, Hangzhou, Zhejiang Province, China
}

\section{Key Words}

HBV-related compensated cirrhosis • Nephritic function • ETV • LDT • eGFR

\begin{abstract}
Background: To compare the impact of telbivudine (LDT) and entecavir (ETV) administration on nephritic function. Method: One hundred thirty patients diagnosed with hepatitis B virus (HBV)-related compensated cirrhosis were randomly divided into LDT $(600 \mathrm{mg} / \mathrm{d})$ or ETV $(0.5 \mathrm{mg} / \mathrm{d})$ groups. Results: The drug resistance rate was higher following LDT treatment compared to ETV treatment ( $16.9 \%$ vs. $1.5 \%, P=0.0006)$. The mean creatinine level decreased compared to baseline in the LDT group ( $0.81 \mathrm{vs.} 0.94 \mathrm{mg} / \mathrm{dl}, \mathrm{P}=0.000)$. The change in median glomerular filtration rate (eGFR) compared to baseline in the LTD and ETV groups was 22.3 and -3.3 , respectively, at 2 years $(P=0.000)$. In patients with mild nephritic injury (eGFR $<90$ $\left.\mathrm{ml} / \mathrm{min} / 1.73 \mathrm{~m}^{2}\right)$, the median eGFR increased by $28.0 \mathrm{ml} / \mathrm{min} / 1.73 \mathrm{~m}^{2}$ in the LDT group and decreased by $4.3 \mathrm{ml} / \mathrm{min} / 1.73 \mathrm{~m}^{2}$ in the ETV group ( $p=0.000$ ). The eGFR in $88.5 \%$ of patients $(23 / 26)$ from the LDT group increased $>90 \mathrm{ml} / \mathrm{min} / 1.73 \mathrm{~m}^{2}$. The percentage of patients with an eGFR $>90 \mathrm{ml} / \mathrm{min} / 1.73 \mathrm{~m}^{2}$ increased from $60.0 \%$ to $92.3 \%$ in the LDT group and from $64.6 \%$ to $69.2 \%$ in the ETV group. Conclusion: In patients with HBV-related compensated cirrhosis, LDT treatment was more effective in protecting nephritic function and was associated with a higher drug resistance rate, but did not contribute to a better outcome compared with ETV treatment.
\end{abstract}

\section{Introduction}

Hepatitis B virus (HBV) infection is one of the leading causes of liver cirrhosis and hepatocellular carcinoma globally. It is estimated that greater than 100 million people die of liver cirrhosis-associated disease, hepatic failure, and hepatocellular carcinoma (HCC) 
every year worldwide [1]. According to the European Association for the Study of the Liver (EASL) Clinical Practice Guidelines in 2012, the liver cirrhosis rate was 8\%-20\% in those with untreated chronic HBV, and the 5-year cumulative HBV virus-related decompensated cirrhosis rate was approximately $20 \%$ in patients with HBV virus-related compensated cirrhosis [2]. Decompensated cirrhosis developing from HBV virus-related compensated cirrhosis is often correlated with serious complications and a poor prognosis. To date, the 5 -year survival rate of patients with decompensated cirrhosis is only 14\% [3]. Persistent HBV infection and replication promotes liver cirrhosis progression to HCC [4]. It has been reported that sustained suppression of HBV replication is an effective means for preventing hepatic complications, prolonging life, and improving liver function [5-8].

Nucleotide analogues are now regarded as a safe and effective way to inhibit HBV virus replication in chronically infected patients with compensated cirrhosis. These oral anti-viral medications are primarily eliminated by kidneys in an unchanged form, therefore the dose of anti-viral drugs for HBV virus-related compensated cirrhosis need to be accessed for risk of renal events [9]. Adefovir dipivoxil (ADV) causes dose-dependent renal impairment [10] and the glomerular filtration rate (GFR) was shown to be down-regulated following long-term use of ETV and TFD in a retrospective study [11]. LDT inhibits virus replication and high serum HBeAg seroconversion [12-14]. In a recent study, LDT was shown to have a protective role on renal function in anti-HBV therapy by improving GFR after 48 weeks of treatment in patients with chronic hepatitis B (CHB), including patients with compensated liver cirrhosis $[15,16]$. Though it may have side effects on nephritic function, ETV has been suggested to have efficacy and a higher genetic barrier to resistant anti-virals in the clinic setting $[17,18]$. Increasing evidence has shown that treatment with ETV delays clinical progression of liver fibrosis $[19,20]$.

Based on effective anti-viral therapy, the adverse events of nucleotide analog drug administration are drawing more and more attention in long-term treatment. To date, few studies have been performed to systematically evaluate the efficacy and side effects of ETV or LDT treatment compared to baseline. Therefore, we performed a prospective study to compare virologic responses and changes in renal function in HBV virus-related compensated cirrhosis by ETV or LDT monotherapy in this study to determine therapeutic outcome and side effects on HBV virus-related compensated cirrhosis.

\section{Materials and Methods}

Human Subjects and Ethnic Statements

Patients diagnosed with hepatitis B virus-related compensate cirrhosis were enrolled at ShaoXing Municipal Hospital. One hundred thirty patients were randomly assigned 1:1 to receive LDT (600 mg/day) or ETV $(0.50 \mathrm{mg} /$ day). The duration of treatment was $>2$ years. Written informed consent was obtained from all of the enrolled patients and the study was approved by the Ethics Committee of ShaoXing Municipal Hospital.

\section{Inclusion and Exclusion Criteria}

Eligible patients with compensated liver cirrhosis met the following criteria: 1) 18-70 years of age, based on diagnostic criteria of cirrhosis (2010 version) [21]; 2) Child-Turcotte-Pugh (CTP) score < 7; and 3) HBV DNA $\geq 10^{4}$ copies/L. Patients were excluded for the following indications: 1) co-infection with hepatitis C virus, hepatitis D virus, or HIV; and 2) diabetes, high blood pressure, Wilson's disease, autoimmune hepatitis, alcoholic cirrhosis, hepatorenal syndrome or spontaneous bacterial peritonitis, and severe heart, renal, and brain disease.

Follow-up Assessment

Follow-up assessment was performed every 3 months over 2 years after the candidates received the indicated therapy in each group. Blood samples were collected at each time point and the assessment included the following: 1) hepatitis B virus markers (HBsAg, anti-HBsAg, HBeAg, anti-HBeAg, and HBcAg), 
Shen et al.: Comparison of LDT and ETV on Nephritic Function and Drug Resistance in HBV-Related Compensated Cirrhosis Patients

detected by enzyme immunoassays according to the manufacturer's instructions (Abbott Laboratories, Chicago, IL, USA); 2) serum HBV DNA, measured by quantitative PCR (Qiagen Company, Shenzhen, China) and the threshold was 500 copies/ml; and 3) serum creatinine (CR; normal range, 0.5-1.5 mg/dL) was determined using the IDMS-traceable enzymatic method (Purebio Laboratories Ltd., Ningbo, China); and 4) AFP and CT.

eGFR Estimating Equations

An abbreviated modified diet in renal disease (aMDRD) was used to calculate the GEF. The eGFR (mL/ $\mathrm{min} / 1.73 \mathrm{~m}^{2}$ )=186×serum CR (mg/dl) ${ }^{1.154} \times$ age $^{-0.203} \times 0.742$ (if female). Serum eGFR (> $60 \mathrm{mg} / \mathrm{min} / 1.72 \mathrm{~m}^{2}$ and $<90 \mathrm{mg} / \mathrm{min} / 1.73 \mathrm{~m}^{2}$ ) was defined as a mild nephrotic level.

\section{Statistical Analysis}

SPSS18.0 software was used for data analysis (SPSS, Inc., Chicago, IL, USA). The accuracy of the GFR equation was expressed as a percentage \pm SD or mean \pm SD depending on the fit with the Gaussian distribution estimation. Rate comparisons were performed using the $\chi^{2}$ test. A $\mathrm{P}<0.05$ was considered significantly different. Continuous variables were examined using the Mann-Whitney U test between the two groups, while variables from the same group before and after treatment were examined by the Wilcoxon onesample test.

\section{Results}

\section{Basic Characteristic of Included Patients}

One hundred thirty patients diagnosed with hepatitis B virus were recruited; 65 received LDT and 65 received ETV. Basic characteristic were compared between the two groups, as shown in Table 1 . There was no significant difference between the age, gender, HBeAg-positive rate, serum HBV DNA, alanine aminotransferase (ALT), CR, eGFR, and CTP scoring between the two groups $(\mathrm{P}>0.05)$.

Therapy Outcome, Drug Resistance, and Virologic and Biochemical Responses

Over the past 2 years, neither HBeAg seroconversion $(37.0 \%$ vs. $20.0 \%, p=0.441)$ nor HBV DNA negativity ( $80 \%$ vs. $89.2 \%, \mathrm{p}=0.224$ ) was observed in patients from either group. Also, ALT normalization did not differ significantly between the two groups (Table $2)$. The cumulative resistance rate in the LDT-treated group was $(16.9 \%$ [11/65], rtM204I) significantly higher than the ETV-treated group (1.5\% [1/65], rtM204V+rtL180M+rtT184G; $\mathrm{p}$ value $=0.006<0.05$; Fig. 1 ).

Table 1. Baseline characteristics of patients. HBeAg: hepatitis B e antigen; ALT: alanine aminotransferase; TBIL: total bilirubin; CR: creatinine; GFR: glomerular filtration rate; HBV: hepatitis B virus; CTP: Child-Turcotte-Pugh score

\begin{tabular}{llll}
\hline & LDT(n =65) & ETV(n =65) & P value \\
\hline Age & $54.7 \pm 10.4$ & $55.1 \pm 9.8$ & 0.822 \\
Gender (male:female) & $52: 13$ & $51: 14$ & 0.321 \\
HBeAg (\%) & $27(41.5 \%)$ & $25(38.5 \%)$ & 0.159 \\
ALT (U/L) & $63.8 \pm 6.17$ & $62.3 \pm 6.18$ & 0.169 \\
Albumin (g/dL) & $39.1 \pm 5.4$ & $40.2 \pm 5.6$ & 0.256 \\
TBIL $(\mu \mathrm{mol} / \mathrm{L})$ & $48.9(23 \sim 71)$ & $45.7(21 \sim 75)$ & 0.526 \\
CR $(\mathrm{mg} / \mathrm{dL})$ & $0.94 \pm 0.3$ & $0.92 \pm 0.2$ & 0.491 \\
eGFR $\left(\mathrm{mL} / \mathrm{min} / 1.73 \mathrm{~m}^{2}\right)$ & $92.5 \pm 14.1$ & $92.6 \pm 13.7$ & 0.547 \\
HBVDNA (logcopies/mL) & $5.2 \pm 1.2$ & $5.1 \pm 1.1$ & 0.621 \\
CTP scoring & $5.5 \pm 1.4$ & $5.6 \pm 1.3$ & 0.674 \\
\hline
\end{tabular}


Shen et al.: Comparison of $L D T$ and ETV on Nephritic Function and Drug Resistance in HBV-Related Compensated Cirrhosis Patients

Table 2. Comparison of ALT normalization, HBV DNA negativity, HBV seroconversion, and drug resistance

\begin{tabular}{llll}
\hline & LDT $(\mathrm{n}=65)$ & $\mathrm{ETV}(\mathrm{n}=65)$ & P value \\
\hline ALT normalization & & & \\
6 months & $42 / 65(64.6)$ & $43 / 65(66.2)$ & 1.000 \\
12 months & $52 / 65(80.0)$ & $55 / 65(84.6)$ & 0.646 \\
18 months & $51 / 65(78.5)$ & $56 / 65(86.2)$ & 0.358 \\
24 months & $56 / 65(86.2)$ & $57 / 65(87.7)$ & 1.000 \\
HBV DNA negativity & & & \\
6 months & $40 / 65(61.5)$ & $43 / 65(66.2)$ & 0.715 \\
12 months & $47 / 65(72.3)$ & $50 / 65(76.9)$ & 0.687 \\
18 months & $48 / 65(73.8)$ & $55 / 65(84.6)$ & 0.195 \\
24 months & $52 / 65(80.0)$ & $58 / 65(89.2)$ & 0.224 \\
HBeAg seroconversion & & & \\
6 months & $4 / 27(14.8)$ & $2 / 25(8.0)$ & 0.738 \\
12 months & $6 / 27(22.2)$ & $3 / 25(12.0)$ & 0.544 \\
18 months & $7 / 27(25.9)$ & $4 / 25(16.0)$ & 0.592 \\
24 months & $9 / 27(37.0)$ & $5 / 25(20.0)$ & 0.441 \\
Drug resistance & & & \\
6 months & $1 / 65(1.5)$ & $0 / 65(0)$ & 1.000 \\
12 months & $3 / 65(4.6)$ & $0 / 65(0)$ & 0.243 \\
18 months & $7 / 65(10.8)$ & $1 / 65(1.5)$ & 0.068 \\
24 months & $11 / 65(16.9)$ & $1 / 65(1.5)$ & 0.006 \\
\hline
\end{tabular}

Fig. 1. Comparison of therapeutic outcomes in the LDTand ETV-treated groups. Analysis of mean ALT normalization, HBV DNA-negative, HBeAg seroconversion, and drug resistant rates over 2 years by LDT or ETV treatment. $\mathrm{P}<0.05$, significantly different.

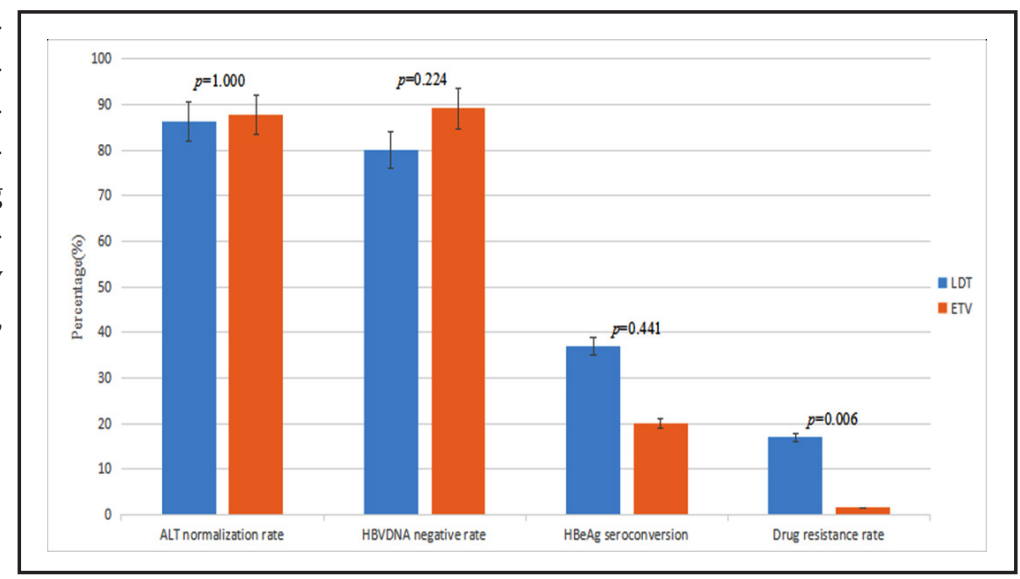

Fig. 2. The mean CR level of different time points in the LDT- or ETV-treated group. Measurement of serum creatinine $(\mathrm{mg} / \mathrm{dL})$ of LDT- or ETV-treated group at $0,6,12$, 18, and 24 months. Each dot represents one single time point.

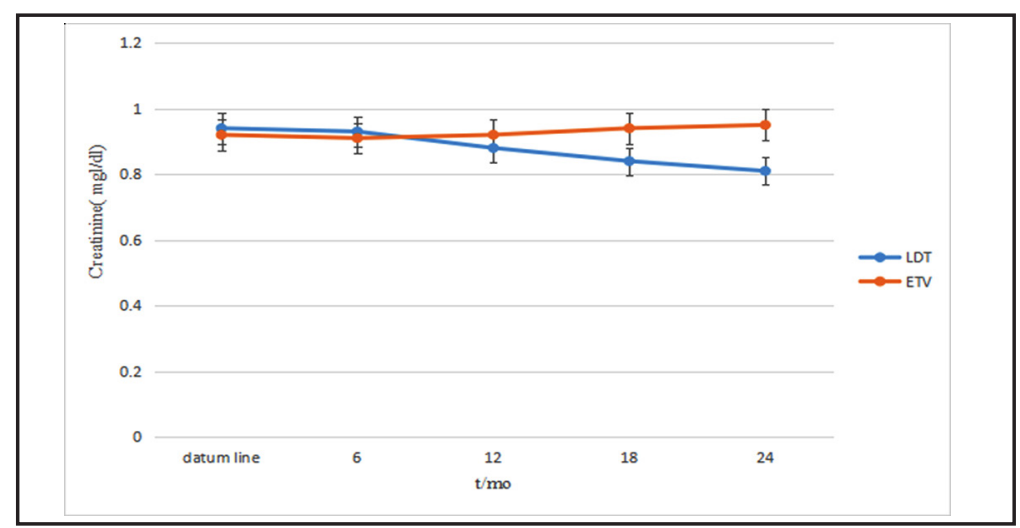

Changes in serum creatinine level

The mean CR levels at different time points in the LDT- and ETV-treated groups are shown in Figure 2. The mean CR level decreased significantly compared to baseline (0.81 vs. $0.94 \mathrm{mg} / \mathrm{dL}, \mathrm{P}=0.001) 2$ years after LDT treatment, while there was an increasing trend in 
Shen et al.: Comparison of $L D T$ and ETV on Nephritic Function and Drug Resistance in HBV-Related Compensated Cirrhosis Patients

Table 3. Change in median eGFR compared with baseline in treatment groups

\begin{tabular}{|c|c|c|c|c|}
\hline & \multirow[t]{2}{*}{$\begin{array}{c}\text { Baseline } \\
\text { eGFR }\left(\mathrm{ml} / \mathrm{min} / 1.73 \mathrm{~m}^{2}\right)\end{array}$} & \multirow[t]{2}{*}{$\mathrm{n} \%$} & \multicolumn{2}{|c|}{$\begin{array}{l}2 \text { years } \\
\text { eGFR }\left(\mathrm{ml} / \mathrm{min} / 1.73 \mathrm{~m}^{2}\right)\end{array}$} \\
\hline & & & $60-90$ & $>90$ \\
\hline \multirow[t]{3}{*}{ LDT group } & $60-90$ & $26(40.0)$ & $3(11.5)$ & $23(88.5)$ \\
\hline & $>90$ & $39(60.0)$ & $2(5.1)$ & 37 (94.9) \\
\hline & Total & $65(100.0)$ & $5(7.7)$ & $60(92.3)$ \\
\hline \multirow[t]{3}{*}{ ETV group } & $60-90$ & $23(35.4)$ & $15(65.3)$ & $8(34.7)$ \\
\hline & $>90$ & $42(64.6)$ & $5(11.9)$ & $37(88.1)$ \\
\hline & Total & $65(100.0)$ & $20(30.8)$ & $45(69.2)$ \\
\hline
\end{tabular}

Fig. 3. The mean eGFR of different time points in the LDT- or ETV treated group. Measurement of serum eGFR ( $\left.\mathrm{mL} / \mathrm{min} / 1.73 \mathrm{~m}^{2}\right)$ of LDT- or ETV-treated group at 0 , $6,12,18$, and 24 months. Each dot represents one single time point.

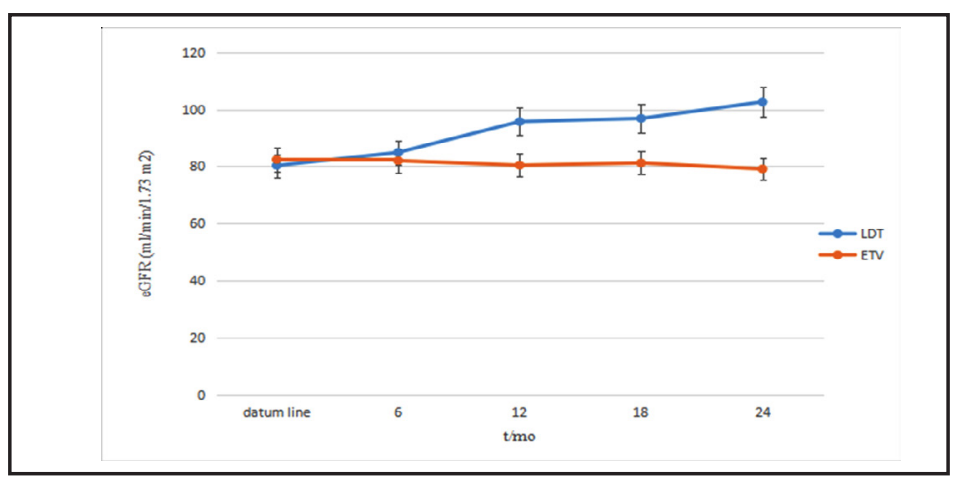

Fig. 4. The median eGFR at different time points in the LDT- or ETV treated group. Measurement of median serum eGFR $\left(\mathrm{mL} / \mathrm{min} / 1.73 \mathrm{~m}^{2}\right)$ in the LDT- or ETV-treated group at 0, 12, and 24 months. Each dot represents one single time point.

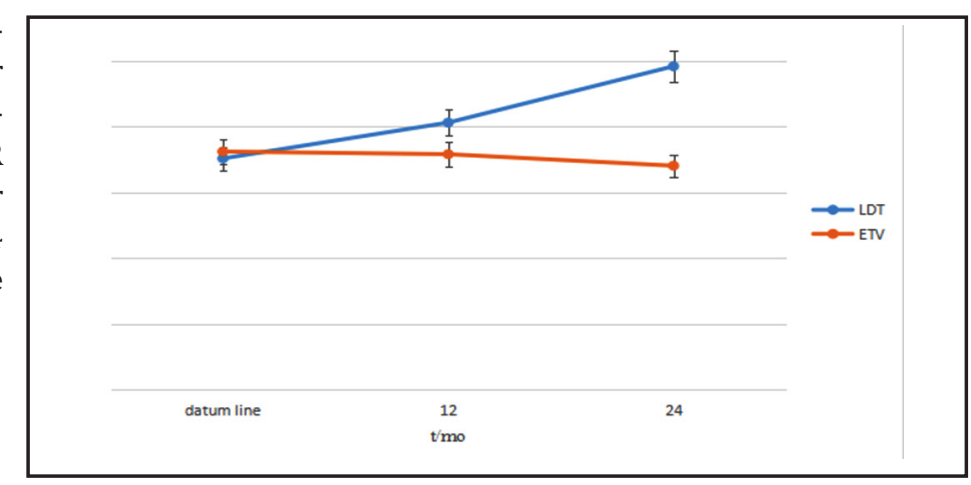

the ETV-treated group compared to baseline (0.95 vs. $0.92 \mathrm{mg} / \mathrm{dL}, \mathrm{p}=0.065$ ). An increase > 0.5 or $1.5 \mathrm{mg} / \mathrm{dL}$ in the mean CR level was not observed in either group, respectively, over the past 2 years (Fig. 2).

\section{Changes in eGFR}

After 2 years of treatment, patients who received LDT treatment had a significantly higher eGFR (102.6 vs. $80.3 \mathrm{ml} / \mathrm{min} / 1.73 \mathrm{~m}^{2}, \mathrm{p}=0.000$ ) compared to baseline (Fig. 3); however, the eGFR decreased compared to baseline after ETV treatment (79.1 vs. $82.4 \mathrm{ml}$ / $\left.\min / 1.73 \mathrm{~m}^{2}, \mathrm{p}=0.063\right)$.

eGFR changes after mild nephrotic injury at baseline in the LDT- and ETV-treated group

One hundred thirty patients with normal CR levels and an eGFR $>60 \mathrm{ml} / \mathrm{min} / 1.73 \mathrm{~m}^{2}$ were included in the study. Forty-nine patients (LDT, n=26; ETV, n=23) had mild nephrotic injury with an eGFR between 60 and $90 \mathrm{ml} / \mathrm{min} / 1.73 \mathrm{~m}^{2}$. As shown in Table 3, over the past 2 years the eGFR was $>90 \mathrm{ml} / \mathrm{min} / 1.73 \mathrm{~m}^{2}$ in $88.5 \%$ of patients $(23 / 26)$ in the LDT-treated group and $34.7 \%$ of patients $(8 / 23)$ in the ETV-treated group, indicating that nephritic function normalized more quickly in the LDT-treated group than the ETV-treated group $\left(\chi^{2}=12.91, P=0.000\right)$. The median eGFR at 2 years was significantly increased compared to baseline (98.3 vs. $70.3 \mathrm{ml} / \mathrm{min} / 1.73 \mathrm{~m}^{2}, \mathrm{p}=0.000$ ) after LDT administration, while significantly decreased after ETV treatment (68.1vs $72.4 \mathrm{ml} / \mathrm{min} / 1.73 \mathrm{~m}^{2}, \mathrm{p}=0.062$; Fig. 4). 


\section{Adverse Events}

No severe adverse events occurred during the 2-year treatment. Six patients had elevated creatine phosphokinase (CK) levels, including 4 patients with primary and 2 patients with secondary elevations (9.2\%). Only two patients had primary CK in elevations $(3.1 \%)$. The symptoms gradually returned to normal during therapy.

\section{Discussion}

Persistent viral replication and viral-related immune responses are major risk factors for disease progression to cirrhosis or HCC. Sustained suppression or elimination of HBV replication is the ultimate goals of HBV treatment [22,23]. Nucleotide analogues are currently regarded as standard treatment for patients with chronic hepatitis B over 10 years by effectively inhibiting HBV virus replication to prevent development of hepatic complications, as well as cirrhosis, hepatic decompensation, and HCC. It has been reported that HBV DNA negativity, ALT normalization, and liver pathology would improve significantly following LDT or ETV monotherapy [12-14, 17-20]; however, a comparison of the therapeutic outcomes in HBV virus-related compensated cirrhosis has rarely been the subject of investigation. In the current study, we compared the therapeutic outcomes, especially with respect to renal function, in patients with HBV-virus related compensated cirrhosis following LDT or ETV monotherapy over 2 years. Specifically, we found that there was no significant difference in ALT normalization, HBV DNA negativity, and HBeAg serum seroconversion in the LDT- and ETV-treated groups $(\mathrm{P}>0.05)$, which is agreement with the reported findings in CHB patients [24]. In addition, the LDT drug-resistant rate was $16.9 \%(11 / 65)$, which was significantly higher than the ETV-treated group (1.5\% [1/65]), thus indicating that patients are more resistant to LDT administration ( $\mathrm{P}=0.006)$. The LDT drug-resistance in our study was lower than that reported in the GLOBE study [13], probably due to the lower HBV DNA replication and higher HBV DNA negativity at 6 and 12 months in the LDT-treated group in our study.

Renal function is considered to be a vital factor in CHB, especially in patients with cirrhosis, and has been shown to be associated with mortality [25]. With the development of liver cirrhosis, maintenance of renal function is associated with a better survival rate. Therefore, the outcome of an optimal nucleotide analogue should be long-lasting HBV DNA inhibition and higher HBeAg serum seroconversion, but low renal toxicity. Currently, nucleotide analogues are metabolized through the kidney and renal failure may be attributable to drug administration [26]. Mauss et al. [27] showed that in 200 CHB patients undergoing LAM, ADV, ETV, and TDF monotherapy for 24 months, the median eGFR decreased by $0.92,1.02,1.00$, and $0.92 \mathrm{ml} / \mathrm{min}$ every year, respectively, according to the Chronic Kidney Disease Epidemiology Collaboration (CKD-EPI) calculation, indicating that mild renal failure may occur during therapy. Recently, some retrospective studies have reported that except for anti-viral treatment, LDT can also help improve the GFR in patients [28, 29]. A doubleblind randomized controlled study showed that the mean eGFR increased $8.5 \%$ compared to baseline after LDT treatment for 2 years and this improvement persisted for 4-6 years, especially in elderly patients with mild renal impairment at baseline [15]. It has recently been reported that compared to LAM, LDT significantly improves the eGFR and survival rate in HBV-related compensated cirrhosis [30].

Changes in CR and GFR were shown before and after LDT or ETV treatment in the current study, and we found a gradually decreased CR level in LDT-treated patients, but no changes in the ETV-treated group ( $\mathrm{p}=0.000$ vs. $\mathrm{p}=0.065$ ). While 130 patients had a normal CR level, in 49 patients the eGFR at baseline was between 60 and $90 \mathrm{ml} / \mathrm{min} / 1.73 \mathrm{~m}^{2}$, indicating that CR may not be a good marker for evaluating renal function; indeed, GFR may more accurate in estimating renal function.

Our study confirmed the protective role of LDT treatment on renal function compared with ETV treatment. We found that after 2 years of treatment, the median eGFR increased by $22.3 \mathrm{ml} / \mathrm{min} / 1.73 \mathrm{~m}^{2}$ and the percentage of patients with an eGFR $>90 \mathrm{ml} / \mathrm{min} / 1.73 \mathrm{~m}^{2}$ 
increased from $60 \%$ to $92.3 \%$ over 2 years, which is agreement with Gane et al. [15] and Lee et al [29]. In addition, 23 patients (88.5\%) in whom the eGFR was $<90 \mathrm{ml} / \mathrm{min} / 1.73 \mathrm{~m}^{2}$ at baseline in the LDT-treated group, returned to normal renal function after oral LDT administration, which was significantly higher than the ETV-treated group ( $n=8$ [34.7\%]). Our results first compared the therapeutic outcome, as well as renal function following LDT or ETV treatment, and confirmed that LDT is superior to ETV in protecting renal function in patients with HBV virus-related compensated cirrhosis with mild nephrotic injury.-

Our study had limitations, as the percentage and degree of renal improvement was higher than previous studies. The limited sample size, strict inclusion and exclusion criteria, and the application of the MDRD equation may have attributed to the discrepant results among previous studies. In general, however, our results are similar to the conclusions of large-scaled randomized controlled trials.

\section{Conclusion}

This study demonstrated that compared to ETV treatment, LDT not only strongly inhibits viral replication, but improves renal function effectively in patients with HBV virusrelated compensated cirrhosis at baseline with a higher drug resistance rate. These findings need to be validated in further prospective and large-scale sample studies with long-term follow-up.

\section{Acknowledgements}

The authors thank all the patients who participated in the study, and Jianping Zhong, Xuefang Chen,and all other clinical staff at Department of Hepatology, ShaoXing Municipal Hospital for their help in completion of this study.

\section{Disclosure Statement}

The authors declare no conflict of interest.

\section{References}

1 McMahon BJ: Epidemiology and natural history of hepatitis b. Semin Liver Dis 2005;25:3-8.

2 European Association For The Study Of The Liver: EASL Clinical Practice Guidelines: Management of chronic hepatitis B virus infection. J Hepatol 2012;57:167-185.

3 Liaw Y-F, Chu C-M: Hepatitis b virus infection. The Lancet 2009;373:582-592.

4 Chen Y-C, Chu C-M, Yeh C-T, Liaw Y-F: Natural course following the onset of cirrhosis in patients with chronic hepatitis b: A long-term follow-up study. Hepatol Int 2007;1:267-273.

5 Shim JH, Lee HC, Kim KM, Lim YS, Chung YH, Lee YS, Suh DJ: Efficacy of entecavir in treatment-naive patients with hepatitis B virus-related decompensated cirrhosis. J Hepatol 2010;52:176-182.

6 Liaw YF, Raptopoulou-Gigi M, Cheinquer H, Sarin SK, Tanwandee T, Leung N, Peng CY, Myers RP, Brown RS Jr, Jeffers L, Tsai N, Bialkowska J, Tang S,Beebe S, Cooney E: Efficacy and safety of entecavir versus adefovir in chronic hepatitis B patients with hepatic decompensation: A randomized, open-label study. Hepatology 2011;54:91-100.

7 Buti M: 21 Two Years Safety And Efficacy Of Tenofovir Disoproxil Fumarate (Tdf) In Patients With HbvInduced Cirrhosis. J Hepatol 2009;50:S10-S11.

8 Gane EJ, Chan HL, Choudhuri G, Suh DJ, Chutaputti A, Safadi R: Treatment of decompensated HBV-cirrhosis: results from 2-year randomized trial with telbivudine or lamivudine. J Hepatol 2010; 52:S4. 
Shen et al.: Comparison of LDT and ETV on Nephritic Function and Drug Resistance in HBV-Related Compensated Cirrhosis Patients

9 Fontana RJ: Side Effects of Long-Term Oral Antiviral Therapy for Hepatitis B. Hepatology 2009;49:S185-S195.

10 Kim YJ, Cho HC, Sinn DH, Gwak GY, Choi MS, Koh KC, Paik SW, Yoo BC, Lee JH: Frequency and risk factors of renal impairment during long-term adefovir dipivoxil treatment in chronic hepatitis b patients. J Gastroenterol Hepatol 2012;27:306-312.

11 Gish RG, Clark MD, Kane SD, Shaw RE, Mangahas MF, Baqai S: Similar risk of renal events among patients treated with tenofovir or entecavir for chronic hepatitis b. Clin Gastroenterol Hepatol 2012;10:941-946.

12 Lai CL, Gane E, Liaw YF, Hsu CW, Thongsawat S, Wang Y, Chen Y, Heathcote EJ, Rasenack J, Bzowej N, Naoumov NV, Di Bisceglie AM, Zeuzem S, Moon YM, Goodman Z, Chao G, Constance BF, Brown NA; Globe Study Group: Telbivudine versus lamivudine in patients with chronic hepatitis B. N Engl J Med 2007;357:2576-2588.

13 Liaw YF, Gane E, Leung N, Zeuzem S, Wang Y, Lai CL, Heathcote EJ, Manns M, Bzowej N, Niu J, Han SH, Hwang SG, Cakaloglu Y, Tong MJ, Papatheodoridis G, Chen Y, Brown NA, Albanis E, Galil K, Naoumov NV; GLOBE Study Group: 2-Year GLOBE trial results: telbivudine Is superior to lamivudine in patients with chronic hepatitis B. Gastroenterology 2009;136:486-495.

14 Matthews SJ: Telbivudine for the management of chronic hepatitis B virus infection. Clin Ther 2007;29: 2635-2653.

15 Gane EJ, Deray G, Liaw Y-F, Lim SG, Lai C-L, Rasenack J, Wang Y, Papatheodoridis G, Di Bisceglie A, Buti M: Telbivudine improves renal function in patients with chronic hepatitis b. Gastroenterology 2014;146:138146. e135.

16 Sun J, Xie Q Tan D, Ning Q, Niu J, Bai X, Fan R, Chen S, Cheng J, Yu Y, Wang H, Xu M, Shi G, Wan M, Chen X, Tang H, Sheng J, Dou X, Shi J, Ren H,Wang M, Zhang H, Gao Z, Chen C, Ma H, Jia J, Hou J: The 104week efficacy and safety of telbivudine-based optimization strategy in chronic hepatitis b patients: A randomized, controlled study. Hepatology 2014;59:1283-1292.

17 Chang TT, Gish RG, de Man R, Gadano A, Sollano J, Chao YC, Lok AS, Han KH, Goodman Z, Zhu J, Cross A, DeHertogh D, Wilber R, Colonno R, Apelian D; BEHoLD AI463022 Study Group: A comparison of entecavir and lamivudine for HBeAg-positive chronic hepatitis B. N Engl J Med 2006;354:1001-1010.

18 Lai CL, Shouval D, Lok AS, Chang TT, Cheinquer H, Goodman Z, DeHertogh D, Wilber R, Zink RC, Cross A, Colonno R, Fernandes L; BEHoLD AI463027 Study Group: Entecavir versus lamivudine for patients with HBeAg-negative chronic hepatitis B. N Engl J Med 2006;354:1011-1020.

19 Schiff E, Simsek H, Lee WM, Chao YC, Sette H Jr, Janssen HL, Han SH, Goodman Z, Yang J, Brett-Smith H, Tamez R: Efficacy and safety of entecavir in patients with chronic hepatitis B and advanced hepatic fibrosis or cirrhosis. Am J Gastroenterol 2008;103:2776-2783.

20 Chang TT, Liaw YF, Wu SS, Schiff E, Han KH, Lai CL, Safadi R, Lee SS, Halota W, Goodman Z, Chi YC, Zhang H, Hindes R, Iloeje U, Beebe S, Kreter B: Long-term entecavir therapy results in the reversal of fibrosis/ cirrhosis and continued histological improvement in patients with chronic hepatitis B. Hepatology. 2010;52:886-893.

21 Chinese Society of Hepatology and Chinese Socity of Infectious Diseases CMA: The guideline of prevent ion and treatment for chronic hepatiti b (2010 version). Chin J Hepatol 2011;19.

22 Perez-Cameo C, Pons M, Esteban R: New therapeutic perspectives in HBV: when to stop NAs. Liver Int 2014; 34:146-153.

23 Zeng XX, Bian ZX, Wu TX, Fu SF, Ziea E, Woon WT: Traditional Chinese Medicine Syndrome Distribution in Chronic Hepatitis B Populations: A Systematic Review. Am J Chin Med 2011;39:1061-1074.

24 Tsai MC, Lee CM, Chiu KW, Hung CH, Tung WC, Chen CH, Tseng PL, Chang KC, Wang JH, Lu SN, Yen YH, Hu TH: A comparison of telbivudine and entecavir for chronic hepatitis B in real-world clinical practice. J Antimicrob Chemother 2012;67:696-699.

25 Fede G1, D‘Amico G, Arvaniti V, Tsochatzis E, Germani G, Georgiadis D, Morabito A, Burroughs AK: Renal failure and cirrhosis: A systematic review of mortality and prognosis.J Hepatol 2012;56:810-818.

26 Gara N, Zhao X, Collins MT, Chong WH, Kleiner DE, Jake Liang T, Ghany MG, Hoofnagle JH: Renal tubular dysfunction during long-term adefovir or tenofovir therapy in chronic hepatitis B. Aliment Pharmacol Ther 2012;35:1317-1325.

27 Mauss S, Berger F, Filmann N, Hueppe D, Henke J, Hegener P, Athmann C, Schmutz G, Herrmann E: Effect of HBV polymerase inhibitors on renal function in patients with chronic hepatitis B. J Hepatol 2011;55:12351240. 
Cellular Physiology Cell Physiol Biochem 2016;40:370-378

\begin{tabular}{|l|l|l}
\hline DOI: 10.1159/000452552 & (C) 2016 The Author(s). Published by S. Karger AG, Basel
\end{tabular} and Biochemistry

28 Wang Y, Thongsawat S, Gane E, Liaw YF, Jia J, Hou J, Chan H, Papatheodoridis G, Wan M, Niu J, Bao W, Trylesinski A, Naoumov NV: Efficacy and safety of continuous 4-year telbivudine treatment in patients with chronic hepatitis b. J Viral Hepat 2013;20:e37-e46.

29 Lee M, Oh S, Lee HJ, Yeum TS, Lee JH, Yu SJ, Kim HY, Yoon JH, Lee HS, Kim Y: Telbivudine protects renal function in patients with chronic hepatitis b infection in conjunction with adefovir-based combination therapy. J Viral Hepat 2014;21:873-881.

30 Chan HL, Chen YC, Gane EJ, Sarin SK, Suh DJ, Piratvisuth T, Prabhakar B, Hwang SG, Choudhuri G, Safadi R, Tanwandee T, Chutaputti A, Yurdaydin C,Bao W, Avila C, Trylesinski A: Randomized clinical trial: Efficacy and safety of telbivudine and lamivudine in treatment-naïve patients with hbv-related decompensated cirrhosis. J Viral Hepat 2012;19:732-743. 